\title{
Pattern of RNA Transcription during Bacillus subtilis Spore Outgrowth
}

\author{
By ALESSANDRA M. ALBERTINI AND ALESSANDRO GALIZZI* \\ Istituto de Genetica, Università di Pavia, Via S. Epifanio 14, 27100 Pavia, Italy
}

(Received 10 February 1981)

\begin{abstract}
During early outgrowth of Bacillus subtilis spores, there is a period of RNA and protein synthesis in the absence of DNA replication. Two mutants of $B$. subtilis, PB2442 (gsp-4) and PB2452 ( $g s p-81)$, were used to study the pattern of RNA synthesis during this period. The two mutants are temperature-sensitive in the outgrowth phase, and show a limited amount of incorporation of $\left[{ }^{3} \mathrm{H}\right]$ uridine at $47^{\circ} \mathrm{C}$. The RNAs synthesized during a $2 \mathrm{~min}$ pulse with $\left[{ }^{3} \mathrm{H}\right]$ uridine were hybridized to EcoRI-digested DNA, after agarose gel electrophoresis and transfer to nitrocellulose paper (Southern technique). For both mutants the transcripts synthesized at $35^{\circ} \mathrm{C}$ at different times were different. Differences were also observed in the transcripts made at $47^{\circ} \mathrm{C}$. For both mutants, in the presence of chloramphenicol, the same hybridization pattern was obtained for RNAs pulse-labelled at different periods during outgrowth.
\end{abstract}

\section{INTRODUCTION}

The process of bacterial endospore germination and outgrowth is an interesting system for the study of the regulation of gene expression at a level of complexity intermediate between the bacterial operon and the eukaryotic cell. During outgrowth the synthesis of macromolecules starts with the synthesis of RNA, followed by the synthesis of proteins and, much later, by the synthesis of DNA (Balassa, 1965; Kobayashi et al., 1965). Thus, in this system there is a period during which RNA and protein synthesis occur without concomitant DNA synthesis.

A strict programme of protein synthesis takes place during outgrowth, with different enzymic activities first appearing at different times (Steinberg \& Halvorson, 1968). The order of expression of the genes is independent of their chromosomal location, as shown by the analysis of temperature-sensitive mutants (Albertini et al., 1979) and by the use of chromosomal translocations (Yeh \& Steinberg, 1978).

The synthesis of proteins is dependent on previous RNA synthesis, suggesting that different messenger RNAs should be present at different periods during outgrowth, if regulation occurs at the level of transcription. Hansen et al. (1970) have analysed the differences and similarities between mRNAs synthesized at different times during outgrowth of Bacillus cereus spores, by means of DNA hybridization experiments with labelled RNA and competition with unlabelled RNA. The data show that there is a fluctuation in the appearance of predominant unstable RNA species. More recently, Silberstein \& Cohen (1978), using hybridization of pulse-labelled RNA to EcoRI DNA fragments in the presence of competing unlabelled RNA, found very few differences in the hybridization pattern of RNA pulse-labelled at different periods during outgrowth of $B$. cereus spores. In Bacillus subtilis, experiments involving hybridization of pulse-labelled RNA to separate $\mathrm{H}$ and $\mathrm{L}$ strands of DNA, coupled to competition with unlabelled RNA, have revealed that during the germination process unique RNAs are transcribed which are absent from exponential-phase cells, and changes in the transcription pattern occur during outgrowth (Margulies et al., 1978; Setoguchi et al., 1978). 
The isolation of mutants defective only in the outgrowth phase of spore germination may help in elucidating the control mechanisms regulating this process (Albertini et al., 1979). In the work described in this paper, we employed two mutant strains (bearing the mutations $g s p-4$ and $g s p-81$ ) impaired in RNA synthesis during outgrowth at $47^{\circ} \mathrm{C}$ to study the pattern of transcription during the outgrowth of spores of $B$. subtilis. The RNA, pulse-labelled at different times, was hybridized to electrophoretically separated EcoRI fragments of $B$. subtilis DNA (Southern, 1975). For both mutants we found that the transcripts synthesized at $35^{\circ} \mathrm{C}$ at different times were different. Differences were also observed at $47^{\circ} \mathrm{C}$. For both mutants, in the presence of chloramphenicol, only an early portion of the programme was realized.

\section{METHODS}

Bacteria and phage. Two Bacillus subtilis strains that are temperature-sensitive in spore germination were used: PB2442 (hisH2 trpC2 gsp-4) (Albertini et al., 1979) and PB2452 (pyrA26 trpC2 gsp-81). Strain PB2452 was constructed by marker congression in transformation, using DNA extracted from strain PB2427 (Albertini \& Galizzi, 1975) and competent cells of the strain PB1715 (pyrA26 lys-3 trpC2): selection was for Lys ${ }^{+}$and the transformants were scored for the thermosensitive gsp unselected marker. Strain PB1424 (hisH2 trpC2 metD4) was used to prepare unlabelled ribosomal RNA and DNA for the hybridization competition experiments. Labelled phage SPP1 DNA was prepared by phenol extraction from CsCl-purified phage previously labelled with [methyl ${ }^{3} \mathrm{H}$ ]thymidine $\left(5 \mu \mathrm{Ci} \mathrm{ml}^{-1}\right)$ by growing the phage on the bacterial strain PB566/1 (thyA thyB).

Media. For RNA labelling, M9 minimal salt medium (Clowes \& Hayes, 1968) was diluted threefold with distilled water, supplemented with $0.2 \%(\mathrm{w} / \mathrm{v})$ Casamino acids (Difco), $0.5 \%(\mathrm{w} / \mathrm{v})$ glucose and $50 \mu \mathrm{g} \mathrm{ml}^{-1}$ of each of the amino acids required for growth. For growth of strain PB1424 for the purification of DNA and ribosomal RNA, Penassay broth (antibiotic medium no. 3, Difco) was used. For the preparation of phage lysates, PS broth was used (Riva et al., 1968).

Radioactive chemicals. $\left[5-{ }^{3} \mathrm{H}\right]$ Uridine (specific activity $25-30 \mathrm{Ci} \mathrm{mmol}{ }^{-1}, 0.9-1 \cdot 1 \mathrm{TBq} \mathrm{mmol}^{-1}$ ) and [methyl ${ }^{3} \mathrm{H}$ ] thymidine (specific activity $18 \mathrm{Ci} \mathrm{mmol}^{-1}, 670 \mathrm{GBq} \mathrm{mmol}^{-1}$ ) were obtained from Amersham.

Labelling of RNA. Spores, purified according to Siccardi et al. (1975) and heat-activated at $70^{\circ} \mathrm{C}$ for $15 \mathrm{~min}$, were resuspended in $200 \mathrm{ml}$ of $\mathrm{M} 9$ medium at an $A_{560}$ of about 0.60 and incubated at the desired temperature. RNA was labelled at different times after the onset of spore germination by a $2 \mathrm{~min}$ pulse of $\left[{ }^{3} \mathrm{H}\right]$ uridine at a final concentration of $5 \mu \mathrm{Ci} \mathrm{ml}^{-1}$. Labelling was stopped by transferring the cultures to a salt/ice mixture and adding 50 $\mathrm{ml}$ of cold $\mathrm{M} 9$ medium and $50 \mu \mathrm{g}$ sodium azide $\mathrm{ml}^{-1}$. Cells were collected with centrifugation, washed twice with cold $\mathrm{M} 9$ medium and stored at $-20^{\circ} \mathrm{C}$.

Purification of RNA. Labelled bacteria were resuspended in $2 \mathrm{ml}$ of DNAase buffer containing $10 \mathrm{~mm}$-sodium acetate, $50 \mathrm{~mm}-\mathrm{NaCl}, 1 \mathrm{~mm}-\mathrm{MnCl}_{2}$ and $50 \mu \mathrm{g}$ pancreatic deoxyribonuclease $\mathrm{ml}^{-1}$ (ribonuclease free, Boehringer). Glass beads $(0.1 \mathrm{~mm}$ diam., $2 \mathrm{~g})$ were added and the suspension was sonicated in pulses for a total of $15 \mathrm{~min}$ in a salt/ice bath. After sonication the broken cells were incubated at $0{ }^{\circ} \mathrm{C}$ for $90 \mathrm{~min}$. The DNAase reaction was stopped by adding EDTA at a final concentration of $2 \mathrm{mM}$. RNA was extracted at $60^{\circ} \mathrm{C}$ with $2 \mathrm{ml}$ of water-saturated phenol. The aqueous phase, separated by centrifugation, was re-extracted twice and, after addition of $\mathrm{KCl}$ to $0.5 \mathrm{M}$ final concentration, was filtered (Selectron filter BA85, $0.45 \mu \mathrm{m}$ pore size; Schleicher \& Schüll). The RNA was precipitated with 3 vol. cold ethanol. After standing at least one night at $-20^{\circ} \mathrm{C}$ the precipitate was collected by centrifugation at $15000 \mathrm{rev}$. $\mathrm{min}^{-1}$ for $15 \mathrm{~min}$ and dissolved with $1 \mathrm{ml}$ of $6 \times \mathrm{SSC}$ buffer $(0.9 \mathrm{M}-\mathrm{NaCl}$, 0.09 M-trisodium citrate).

The unlabelled ribosomal RNA was prepared from ribosomes according to Traub et al. (1971).

EcoRI digestion. DNA was extracted from cells as described by Saito \& Miura (1963) and treated with sufficient EcoRI restriction endonuclease (Bethesda Research Laboratories and Miles Laboratories) to give complete digestion in $3 \mathrm{~h}$ at $37^{\circ} \mathrm{C}$. The reaction mixture was prepared according to the manufacturer's instructions. Restriction fragments were subjected to electrophoresis in $1 \%(\mathrm{w} / \mathrm{v})$ agarose (Bio-Rad) slab gels with tris/acetate buffer, as described by Cohen et al. (1973), and in the presence of $1 \mu \mathrm{g}$ ethidium bromide $\mathrm{ml}^{-1}$. Electrophoretic patterns were visualized with ultraviolet light.

RNA-DNA hybridization on nitrocellulose strips. The EcoRI-digested B. subtilis DNA fragments were denatured on the gel and transferred to a nitrocellulose membrane (Selectron BA85; Schleicher \& Schüll) as described by Southern (1975). Transfer efficiency was checked using ${ }^{3} \mathrm{H}$-labelled SPP1 DNA and counting the radioactivity bound to nitrocellulose. The efficiency varied between 50 and $100 \%$. Strips $(0.5-1 \mathrm{~cm}$ wide) containing about $5 \mu \mathrm{g}$ of $E c o$ RI-digested $B$. subtilis DNA were cut and baked in a vacuum oven at $80^{\circ} \mathrm{C}$ for $2 \mathrm{~h}$. For hybridization experiments, strips were incubated at $66^{\circ} \mathrm{C}$ for $18 \mathrm{~h}$ in $1.5 \mathrm{ml}$ of $6 \times \mathrm{SSC}$ with $0.5 \times 10^{5}-2 \times$ $10^{5}$ c.p.m. $(5-30 \mu \mathrm{g})$ of $\left[{ }^{3} \mathrm{H}\right]$ uridine-labelled RNA in the presence of $200 \mu \mathrm{g}$ of unlabelled ribosomal RNA. 
Subsequently, the strips were washed with $2 \mathrm{ml}$ of $6 \times \mathrm{SSC}$ at $66^{\circ} \mathrm{C}$ for $1 \mathrm{~h}$, treated with $2 \mathrm{ml}$ of $6 \times \mathrm{SSC}$ containing $25 \mu \mathrm{g}$ pancreatic ribonuclease $\mathrm{A} \mathrm{ml}^{-1}$ and $10 \mathrm{U} \mathrm{T} 1$ ribonuclease $\mathrm{ml}^{-1}$ (Boehringer) for $1 \mathrm{~h}$ at $20^{\circ} \mathrm{C}$, then washed with $2 \mathrm{ml}$ of $6 \times \mathrm{SSC}$ for $2 \mathrm{~h}$ at $20^{\circ} \mathrm{C}$ and dried for $2 \mathrm{~h}$ at $80^{\circ} \mathrm{C}$.

Fluorography. Strips were dipped in a solution of $20 \%(\mathrm{w} / \mathrm{v}) 2,5$-diphenyloxazole in toluene, dried in the air and subjected to fluorography as described by Laskey \& Mills (1975) using Kodak-X-Omat R film (XR-5) preexposed to a single flash of light filtered through a Deep orange, Wratten no. 22 filter (Kodak). The fluorography was performed at $-70^{\circ} \mathrm{C}$ for $15-60 \mathrm{~d} .{ }^{3} \mathrm{H}$-labelled SPP1 DNA EcoRI fragments subjected to agarose electrophoresis, Southern transfer and fluorography were used to estimate molecular weights.

\section{RESULTS}

\section{Hybridization of pulse-labelled RNA during outgrowth at $35^{\circ} \mathrm{C}$}

Total chromosomal DNA of $B$. subtilis was digested with EcoRI endonuclease and the fragments were separated by agarose gel electrophoresis. The DNA was denaturated and transferred to nitrocellulose paper by the method of Southern (1975). RNA pulse-labelled with $\left[{ }^{3} \mathrm{H}\right]$ uridine was hybridized to the DNA paper strips in the presence of unlabelled ribosomal RNA. In our previous work (Galizzi et al., 1976) we have shown that during outgrowth the RNA labelled in a 2 min pulse is $50 \%$ ribosomal. Excess unlabelled ribosomal RNA was therefore added in order to reduce hybridization of ${ }^{3} \mathrm{H}$-labelled ribosomal RNA. As shown by Silberstein \& Cohen (1978), ribosomal RNA gives 18 hybridization bands to EcoRI-digested DNA in B. cereus and we have obtained a similar result in $B$. subtilis (data not shown). Following hybridization, the nitrocellulose strips were saturated with 2,5diphenyloxazole and fluorography was performed. Hybridization with RNA of the outgrowing spores of mutant PB2442 (gsp-4) incubated at $35^{\circ} \mathrm{C}$ and pulse-labelled at 13,25 and $62 \mathrm{~min}$ gave the fluorograms shown in Fig. 1A. Several reproducible hybridization bands could be seen and differences were observed between the samples pulse-labelled at 25 and 62 min from the onset of germination. A similar evolution in the pattern of transcription was seen with the spores of mutant PB2452 (gsp-81), incubated at $35^{\circ} \mathrm{C}$ and pulse-labelled at 13 , 25 and $45 \mathrm{~min}$ (Fig. 1B).

\section{Transcription during outgrowth of mutant PB2442 (gsp-4) spores at $47^{\circ} \mathrm{C}$}

Since the spores of mutant PB2442 (gsp-4) are impaired in RNA synthesis during outgrowth at $47^{\circ} \mathrm{C}$, we have studied the transcripts present at different time intervals after the onset of germination at the non-permissive temperature. Only one difference was observed between the fluorograms corresponding to RNA pulse-labelled at 13, 25 and $62 \mathrm{~min}$ : one band of about 4.6 megadaltons was absent at $13 \mathrm{~min}$, synthesized at $25 \mathrm{~min}$ and had disappeared at 62 min (the band is indicated by 4 in Fig. 3). Thus, at the non-permissive temperature only a variation in the pattern of transcription takes place in mutant PB2442 (gsp-4).

To obtain a further parameter that could be useful in providing a picture of transcription during spore outgrowth, the RNAs were also pulse-labelled in the presence of an inhibitor of protein synthesis. In the presence of chloramphenicol at $47^{\circ} \mathrm{C}\left(47^{\circ} \mathrm{C}-\mathrm{CM}-\mathrm{RNA}\right)$ the same pattern was obtained at different times during outgrowth. Hybridization patterns of the $47^{\circ} \mathrm{C}$-CM-RNAs are shown in Fig. 2 together with the pattern obtained with spores incubated without chloramphenicol at $47^{\circ} \mathrm{C}\left(47^{\circ} \mathrm{C}\right.$-RNA) and labelled at $13 \mathrm{~min}$; no differences were observed. This suggests that in the absence of protein synthesis no transition can occur and the outgrowing spores perform only the first phase of the transcription programme.

The hybridization bands obtained in the three different conditions $\left(35^{\circ} \mathrm{C}, 47^{\circ} \mathrm{C}, 47^{\circ} \mathrm{C}+\right.$ $\mathrm{CM})$ at the same labelling time $(25 \mathrm{~min})$ are shown together in Fig. 3. There were differences between the bands for $35^{\circ} \mathrm{C}$ and the other two conditions. One band present at $47^{\circ} \mathrm{C}$ was missing at $47^{\circ} \mathrm{C}+\mathrm{CM}$ and one band present at $47^{\circ} \mathrm{C}+\mathrm{CM}$ was missing at $47^{\circ} \mathrm{C}$, again 


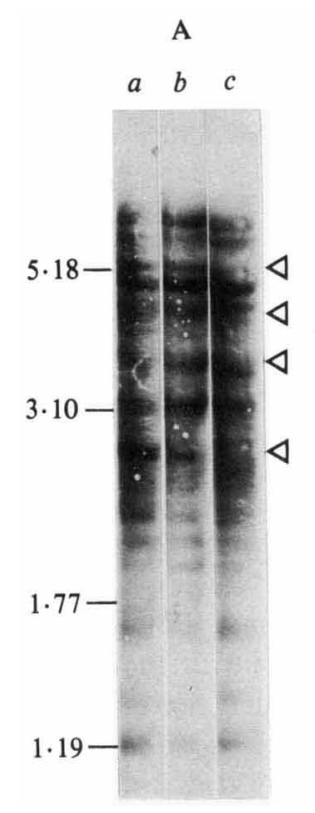

Fig. 1

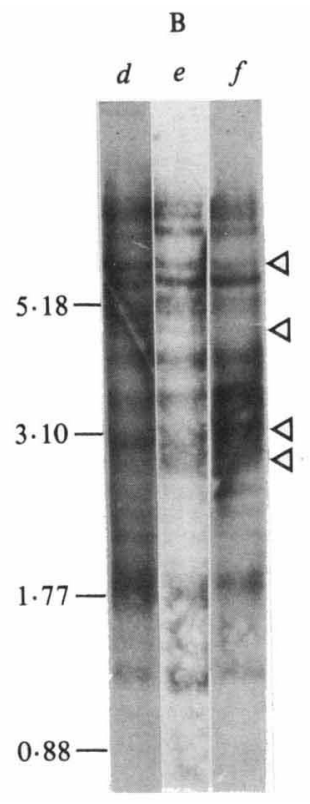

(1)

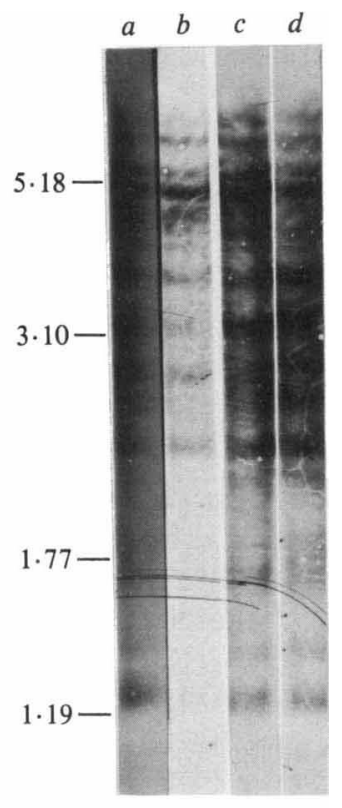

Fig. 2

Fig. 1. Hybridization of RNA pulse-labelled with $\left[{ }^{3} \mathrm{H}\right]$ uridine during spore outgrowth at $35^{\circ} \mathrm{C}$. DNA was digested with $E c o$ RI endonuclease and the fragments were separated by agarose gel electrophoresis. After transfer to nitrocellulose paper the RNA pulse-labelled for 2 min was hybridized in the presence of $200 \mu \mathrm{g}$ of unlabelled ribosomal RNA, as described in Methods. The hybridization pattern was visualized by fluorography.

A: RNA from mutant PB2442 (gsp-4) labelled at 11-13 $\min (a), 23-25 \min (b)$ and 60-62 $\min (c)$ after inoculation. B: RNA from mutant PB2452 (gsp-81) labelled at 11-13 min (d), 23-25 min (e) and 43-45 $\mathrm{min}(f)$ after inoculation. The positions of molecular size markers (in megadaltons) of phage SPP1 $\left[{ }^{3} \mathrm{H}\right]$ DNA digested with EcoRI endonuclease are shown. The $\triangleleft$ indicate differences in the banding patterns observed at different labelling times.

Fig. 2. Hybridization to EcoRI DNA fragments of RNA pulse-labelled during outgrowth at $47^{\circ} \mathrm{C}$ of spores of mutant PB2442 (gsp-4) in the presence and in the absence of chloramphenicol. RNA labelled at 11-13 $\mathrm{min}$ in the absence of chloramphenicol $(a)$; RNA labelled at 11-13 min (b), 23-25 min (c) and 60-62 $\mathrm{min}(d)$ in the presence of chloramphenicol $\left(50 \mu \mathrm{g} \mathrm{m}^{-1}\right)$ from the time of inoculation.

indicating that at $47^{\circ} \mathrm{C}$ the mutant is blocked very early and transcription can go only one step further than the transcription performed in the absence of protein synthesis.

\section{Transcription during outgrowth of mutant PB2452 (gsp-81) spores at $47^{\circ} \mathrm{C}$}

Spores of the mutant PB2452 ( $g s p-81$ ) are also altered in RNA synthesis during outgrowth at $47^{\circ} \mathrm{C}$. From temperature-shift experiments, different temperature-sensitive periods have been assigned to the two mutants, the $g s p-4$ mutation affecting outgrowth earlier than $g s p-81$ (Albertini et al., 1979).

The hybridization patterns of RNA pulse-labelled at 13, 25 and $45 \mathrm{~min}$ of outgrowth at $35^{\circ} \mathrm{C}$ are shown in Fig. 1B. Differences were seen among the transcripts present in the different samples. A changing pattern was also seen at the non-permissive temperature (Fig. 4). Two differences were seen between the samples pulse-labelled at $13 \mathrm{~min}$ and $25 \mathrm{~min}$ and one further difference between those pulse-labelled at $25 \mathrm{~min}$ and $45 \mathrm{~min}$. Thus, in this mutant, even at the non-permissive temperature, there was an evolution in the pattern of RNA synthesis though the changes were fewer than those observed at $35^{\circ} \mathrm{C}$. In the presence of chloramphenicol the same patterns of hybridization bands were seen with RNA pulse-labelled at 13,25 and $45 \mathrm{~min}$. The hybridization patterns obtained with RNA 


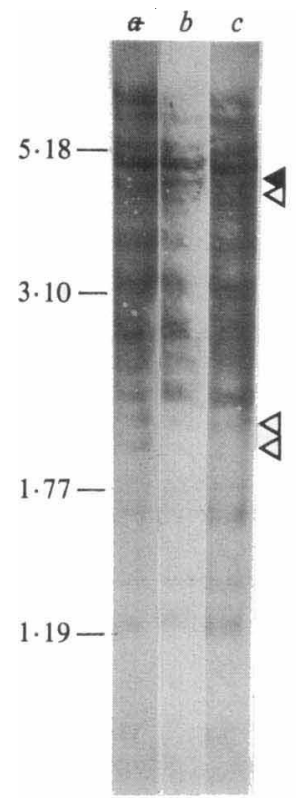

Fig. 3

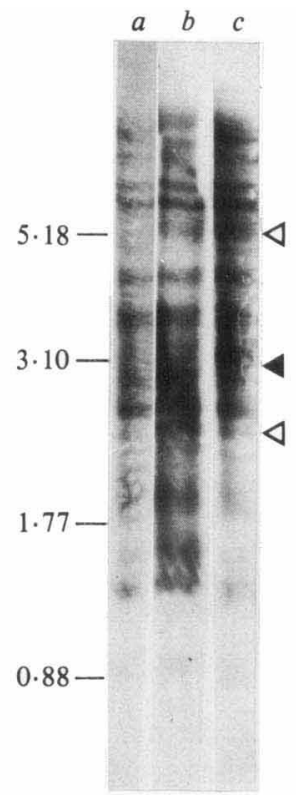

Fig. 4

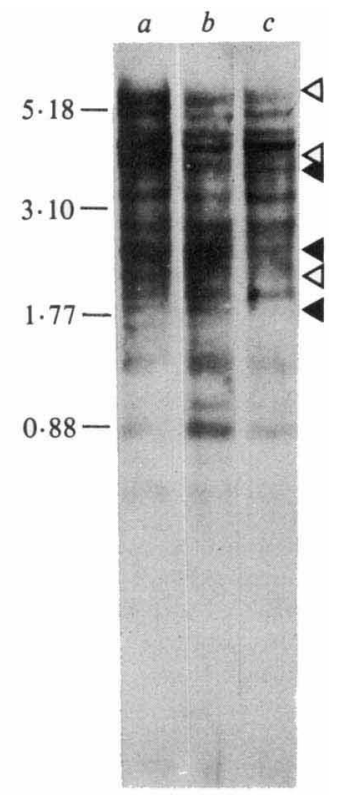

Fig. 5

Fig. 3. Hybridization to EcoRI DNA fragments of RNA pulse-labelled at 23-25 min during outgrowth of spores of mutant PB2442 (gsp-4). Spores incubated at $35^{\circ} \mathrm{C}(a)$, at $47^{\circ} \mathrm{C}(b)$ and at $47^{\circ} \mathrm{C}$ in the presence of chloramphenicol $\left(50 \mu \mathrm{g} \mathrm{ml}^{-1}\right)$ from the time of inoculation $(c)$. The $\triangleleft$ indicate differences in the banding patterns between $(a)$ and $(b) ;$ indicates the difference between $(b)$ and $(c)$.

Fig. 4. Hybridization to EcoRI DNA fragments of RNA pulse-labelled during outgrowth at $47^{\circ} \mathrm{C}$ of spores of mutant PB2452 ( $g s p-81$ ). RNA labelled at 11-13 min (a), 23-25 min $(b)$ and 43-45 min $(c)$ after inoculation. The $\triangleleft$ indicate differences in the banding patterns between $(a)$ and $(b) ; \varangle$ indicates the difference between $(b)$ and $(c)$.

Fig. 5. Hybridization to EcoRI DNA fragments of RNA pulse-labelled at 23-25 min during outgrowth of spores of mutant PB2452 (gsp-8I). Spores incubated at $35^{\circ} \mathrm{C}(a)$, at $47^{\circ} \mathrm{C}(b)$ and at $47{ }^{\circ} \mathrm{C}$ in the presence of chloramphenicol $\left(50 \mu \mathrm{g} \mathrm{ml}^{-1}\right)$ from the time of inoculation $(c)$. The $\triangleleft$ indicate differences in the banding patterns between $(a)$ and $(b) ;$ indicate the differences between $(b)$ and $(c)$.

pulse-labelled at 25 min during outgrowth at $35^{\circ} \mathrm{C}, 47^{\circ} \mathrm{C}$ and $47^{\circ} \mathrm{C}+\mathrm{CM}$ are shown in Fig. 5. Differences were seen between the $35^{\circ} \mathrm{C}$-RNA and the $47^{\circ} \mathrm{C}-\mathrm{RNA}$ and between the $47^{\circ} \mathrm{C}$-RNA and the $47^{\circ} \mathrm{C}$-CM-RNA. In the last case at least three bands present at $47^{\circ} \mathrm{C}$ were missing from the sample labelled in the presence of chloramphenicol. Quantitative differences were also seen in the molecular mass range of 0.88 to 1.77 megadaltons, in particular between $47^{\circ} \mathrm{C}$-RNA and $47^{\circ} \mathrm{C}$-CM-RNA. Thus, at $47^{\circ} \mathrm{C}$ in absence of protein synthesis, the RNA species transcribed are a subset of the transcripts synthesized at the non-permissive temperature.

\section{DISCUSSION}

Even in the earliest period (13-15 min) considered, we did not observe the exclusive synthesis of stable RNA. Similar results were obtained by Margulies et al. (1978). For both strains at $35^{\circ} \mathrm{C}$ a programme of changes in the pattern of RNA hybridization bands takes place during outgrowth. This is consistent with the data of Hansen et al. (1970) and the more recent work of Margulies et al. (1978) and Setoguchi et al. (1978). At the non-permissive temperature the spores of the strain bearing the gsp-4 mutation can perform a very limited amount of change in transcription; in fact only one difference could be detected, namely, a 


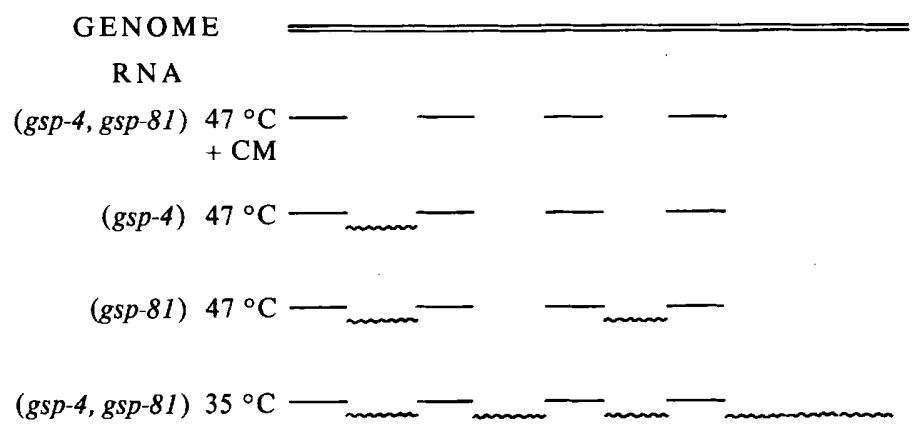

Fig. 6. Interpretation of the results. In both mutants, during outgrowth at $47^{\circ} \mathrm{C}$ in absence of protein synthesis only a limited number of DNA regions can be transcribed: there appears to be no difference between the two mutants in this respect. At $47^{\circ} \mathrm{C}$, mutant PB2442 (gsp-4) is affected in outgrowth at an early stage, and only a second step of the transcription programme can be carried out. Mutant PB2452 (gsp-81) is blocked later during outgrowth and is capable of performing one further step of the programme.

band absent at $13 \mathrm{~min}$ was synthesized at $25 \mathrm{~min}$ and disappeared at $62 \mathrm{~min}$. The pattern observed at $47^{\circ} \mathrm{C}$ is almost identical to that seen with RNA pulse-labelled at $35^{\circ} \mathrm{C}$ in the presence of chloramphenicol. In the latter case no evolution could be detected during the time span considered. Thus, the gsp-4 mutation affects outgrowth transcription at an early stage of the programme. The block is one step further removed with respect to the block in transcription obtained in the presence of chloramphenicol (Fig. 3). We would expect that during outgrowth at the non-permissive temperature, few proteins are synthesized by the spores with the gsp-4 mutation. Preliminary analyses of the newly synthesized proteins by two-dimensional electrophoresis are completely consistent with this prediction (data not shown).

The second mutation examined ( $g s p-81)$ has a less severe effect on the transcription of spores outgrowing at $47^{\circ} \mathrm{C}$. Despite the fact that RNA synthesis is impaired, there is still an evolution in the pattern of hybridization bands, and the mutant spore appears to be capable of performing a number of switches in the programme of RNA synthesis. In this mutant we have previously shown that in the presence of chloramphenicol more RNA is accumulated at $47^{\circ} \mathrm{C}$ and the rate of synthesis is maintained at a higher level for a longer period compared with synthesis at $47^{\circ} \mathrm{C}$ in the absence of the drug (Albertini \& Galizzi, 1975). By quantitative hybridization and competition we showed that only some of the species pulse-labelled were common to $47^{\circ} \mathrm{C}$-RNA and to $47^{\circ} \mathrm{C}$-CM-RNA (Galizzi et al., 1976). From the present data (Fig. 5) it appears that the hybridization pattern of $47^{\circ} \mathrm{C}$-RNA is more complex than that of $47^{\circ} \mathrm{C}-\mathrm{CM}-\mathrm{RNA}$, and that all differences are in the presence of more bands rather than in the absence of any bands.

It has been calculated that the EcoRI endonuclease cuts $B$. subtilis DNA into about 500 fragments (Dean \& Halvorson, 1976), whilst on agarose gels only about 100 bands can be resolved. This means that, on average, each band must comprise several DNA fragments. Consequently, the differences observed between hybridization patterns represent a minimal estimate of the differences between the RNAs tested. On the other hand, similar patterns of hybridization do not necessarily mean that the RNAs under scrutiny are the same; in this case one would expect to obtain different intensities in the hybridization bands. We have purposely avoided considering such differences, due to difficulties involved in a quantitative comparison of samples necessarily hybridized separately and in normalizing the intensities of the different bands. Thus, we have examined only the quality (i.e. electrophoretic mobility) of the hybridization bands obtained by fluorography.

The overall picture emerging from the results presented in this paper is shown schematically in Fig. 6. In the presence of chloramphenicol only a limited number of 
transcripts are present. The realization of the first stage of the programme does not require protein synthesis and the hybridization patterns for both mutant strains are identical (data not shown). The strain with the gsp-4 mutation is blocked very early during outgrowth and can perform only one further step in the transcription programme. The gsp-81 mutation blocks transcription at a later stage during outgrowth, allowing the realization of a larger part of the programme.

The authors would like to thank $\operatorname{Dr}$ G. Milanesi for helpful discussions during the course of this work and the writing of the manuscript, Dr S. Jayakar for reading the manuscript and Lucia Negri for efficient technical assistance. This work was partially supported by C.N.R. grant no. 78.02113.04.

\section{REFERENCES}

Albertini, A. M. \& Galizzi, A. (1975). Mutant of Bacillus subtilis with a temperature-sensitive lesion in ribonucleic acid synthesis during spore germination. Journal of Bacteriology 124, 14-25.

Albertini, A. M., Baldi, M. L., Ferrari, E., IsNenGHI, E., ZAMBelli, M. T. \& GAlizzI, A. (1979). Mutants of Bacillus subtilis affected in spore outgrowth. Journal of General Microbiology 110, 35 1-363.

BALAsSA, G. (1965). Synthèses macromoléculaires au cours de la germination des spores de $B$. subtilis. I. Cinétique. Annales de l'Institut Pasteur 109, 13-35.

Clowes, R. C. \& Hayes, W. (1968). Experiments in Microbial Genetics, p. 187. Oxford: Blackwell Scientific Publications.

Cohen, S. N., Chang, A. C. Y., Boyer, H. W. \& Helling, R. B. (1973). Construction of biologically functional bacterial plasmids "in vitro". Proceedings of the National Academy of Sciences of the United States of America 70, 3240-3244.

DEAN, D. H. \& HALvorson, H. O. (1976). Isolation of polygenic fragments of the Bacillus chromosome: transformation activity of endo EcoRI-fragmented DNA. In Microbiology 1976, pp. 380-387. Edited by D. Schlessinger. Washington, D.C.: American Society for Microbiology.

Galizzi, A., Albertini, A. M., Plevani, P. \& CASSANI, G. (1976). Synthesis of RNA and protein in a mutant of Bacillus subtilis temperature sensitive during spore germination. Molecular and General Genetics 148, 159-164.

Hansen, J. N., Spiegelman, G. \& Halvorson, H. O. (1970). Bacterial spore outgrowth: its regulation. Science 168, 1291-1298.

Kobayashi, Y., Steinberg, W., Higa, A., Halvorson, H. O. \& LeVinthal, C. (1965). Sequential synthesis of macromolecules during outgrowth of bacterial spores. In Spores $I I I$, pp. 200-212. Edited by L. L. Campbell \& H. O. Halvorson. Washington, D.C.: American Society for Microbiology.

LASKEY, D. A. \& Mills, A. D. (1975). Quantitative film detection of ${ }^{3} \mathrm{H}$ and ${ }^{14} \mathrm{C}$ in polyacrylamide gels by fluorography. Journal of Biochemistry 36, 335341 .
Margulies, L., Setoguchi, Y. \& Rudner, R. (1978). Asymmetric transcription during post-germinative development of Bacillus subtilis spores. I. Hybridization patterns. Biochimica et biophysica acta 521, 708-718.

Riva, S., Polsineli., M. \& Falaschi, A. (1968). A new phage of Bacillus subtilis having separable strands. Journal of Molecular Biology 35, 347-356.

SaIto, H. \& MiURA, K. (1963). Preparation of transforming deoxyribonucleic acid by phenol treatment. Biochimica et biophysica acta 72, 619-629.

Setoguchi, Y., Margulies, L. \& Rudner, R. (1978). Asymmetric transcription during post-germinative development of Bacillus subtilis spores. II. Hybrid competition analyses. Biochimica et biophysica acta 521, 719-725.

Siccardi, A. G., Galizzi, A., Mazza, G., Clivio, A. \& Albertini, A. M. (1975). Synchronous germination and outgrowth of fractionated Bacillus subtilis spores: tool for the analysis of differentiation and division of bacterial cells. Journal of Bacteriology 121, 13-19.

Silberstein, Z. \& Cohen, A. (1978). Hybridization analysis of restriction endonuclease DNA fragments of Bacillus cereus transcribed during spore outgrowth. Journal of Bacteriology 134, 1081-1088.

SoutHERN, E. M. (1975). Detection of specific sequences among DNA fragments separated by gel electrophoresis. Journal of Molecular Biology 98, 503-517.

Steinberg, W. \& Halvorson, H. O. (1968). Timing of enzyme synthesis during outgrowth of spores of Bacillus cereus. 1. Ordered enzyme synthesis. Journal of Bacteriology 95, 469-478.

Traub, P., Mizushima, S., Lowry, C. V. \& Nomura, M. (1971). Reconstitution of ribosomes from subribosomal components. Methods in Enzymology 20, $391-407$.

YEH, E. L. \& STEINBERG, W. (1978). The effect of gene position, gene dosage and a regulatory mutation on the temporal sequence of enzyme synthesis accompanying outgrowth of Bacillus subtilis spores. Molecular and General Genetics 158, 287-296. 